\title{
An Acetylcholine Receptor $\alpha$ Subunit Promoter Confers Intrathymic Expression in Transgenic Mice \\ Implications for Tolerance of a Transgenic Self-Antigen and for Autoreactivity in Myasthenia Gravis
}

\author{
Anne-Marie Salmon, ${ }^{*}$ Corinne Bruand, ${ }^{\ddagger}$ Ana Cardona, ${ }^{\S}$ Jean-Pierre Changeux, ${ }^{*}$ and Sonia Berrih-Aknin ${ }^{\star}$ \\ *Unité de Neurobiologie Moléculaire, CNRS URA-1284, Institut Pasteur, 75015 Paris, France; ${ }^{\ddagger}$ Laboratoire de Physiologie Thymique, \\ IPSC, CNRS UPRESA, Hôpital Marie Lannelongue, 92350 Le Plessis-Robinson, France; and ${ }^{\S}$ Laboratoire de Technologie Cellulaire, \\ Institut Pasteur, 75724 Paris cédex 15, France
}

\begin{abstract}
Myasthenia gravis (MG) is an autoimmune disease targeting the skeletal muscle acetylcholine receptor (AChR). Although the autoantigen is present in the thymus, it is not tolerated in MG patients. In addition, the nature of the cell bearing the autoantigen is controversial. To approach these questions, we used two lineages of transgenic mice in which the $\beta$-galactosidase ( $\beta$-gal) gene is under the control of a 842-bp (Tg1) or a 3300-bp promoter fragment ( $\mathrm{Tg} 2)$ of the chick muscle $\alpha$ subunit AChR gene. In addition to expression in muscle cells, thymic expression was observed in both mouse lines (mainly in myoid cells in Tg1 and myoid cells and epithelial cells in Tg2). After challenge with $\beta$-gal, $\mathrm{Tg} 1$ mice produced $\mathrm{Th} 2$-dependent anti- $\beta$-gal antibodies, while Tg2 mice were almost unresponsive. By contrast, in a proliferation assay both $\mathrm{Tg}$ lines were unresponsive to $\beta$-gal. Cells from $\mathrm{Tg} 1$ mice produce $\mathrm{Th}$ 2-dependent cytokine whereas cells from $\mathrm{Tg} 2$ mice were nonproducing in response to $\beta$-gal. These data indicate that the level of expression in $\operatorname{Tg} 1$ mice could be sufficient to induce tolerance of Th1 cells but not of $\mathrm{Th} 2$ cells, while both populations are tolerated in $\mathrm{Tg} 2$ mice. These findings are compatible with the hypothesis that AChR expression is not sufficiently abundant in MG thymus to induce a full tolerance. (J. Clin. Invest. 1998. 101: 2340-2350.) Key words: thymus - myoid cells $•$ epithelial cells $\cdot \mathrm{Th} 1 / \mathrm{Th} 2 \cdot$ antibody response
\end{abstract}

\section{Introduction}

Myasthenia gravis $(\mathrm{MG})^{1}$ is an human neuromuscular disorder characterized by abnormal fatigability, which is partly reversed

\footnotetext{
Address correspondence to Dr. Sonia Berrih-Aknin, Hôpital Marie Lannelongue, CNRS UPRESA, Laboratoire d'Immunologie, 133, avenue de la Résistance, 92350 Le Plessis-Robinson, France. Phone: 33-1-40-94-28-00, ext. 35-65; FAX: 33-1-46-30-45-64; E-mail: berrih@ pratique.fr

Received for publication 27 August 1997 and accepted in revised form 25 March 1998.
}

1. Abbreviations used in this paper: $\mathrm{AChR}$, acetylcholine receptor; $\beta$-gal, $\beta$-galactosidase; $\mathrm{E}$, embryonic day; MG, myasthenia gravis; PN, postnatal day; TEC, thymic epithelial cells; Tg, transgenic.

J. Clin. Invest.

(C) The American Society for Clinical Investigation, Inc. 0021-9738/98/06/2340/11 \$2.00

Volume 101, Number 11, June 1998, 2340-2350

http://www.jci.org by antiacetylcholinesterase drugs. It is widely accepted that the neuromuscular abnormalities in MG are largely due to antibodies directed against the muscle acetylcholine receptor (AChR), which are found in the blood of $85 \%$ of MG patients (1). Most of these antibodies react with the $\alpha$ subunit of AChR, in its main immunogenic region $(2,3)$. These autoantibodies are detrimental for AChR function through several mechanisms; in particular, they reduce the number of AChR at the neuromuscular junction, leading to impaired neuromuscular transmission $(4,5)$.

The thymus plays a central and probably a primary role in MG, since thymectomy is an effective therapy for many patients (6) and since histological abnormalities (hyperplasia or thymoma) are found in $70-80 \%$ of patients (7). Several observations and experimental data point to a relationship between the thymus and anti-AChR antibodies. First, there is a correlation between the antibody titer and thymus pathology (8). Second, B cells purified from hyperplastic thymus tissue spontaneously produce antibodies against AChR in vitro (9). Finally, after thymectomy the anti-AChR antibody titer falls in most patients (10). All these arguments point to an autoimmune response against AChR in the thymus. The presence of the autoantigen in the thymus has been suggested by several studies but its low expression has made it difficult to detect, except in very rare myoid cells (11). Other cell types have also been reported to contain antigens that cross-react with antibodies to AChR (12) namely epithelial cells from thymomas (13). By molecular biology approaches, murine epithelial cell lines from the thymic cortex and medulla, as well as human thymic epithelial cells (TEC) in culture, were shown to express the $\alpha$ subunit AChR mRNA $(14,15)$.

To determine whether the AChR, or cross-reactive antigens, are expressed in the thymus, we studied mice transgenic for the $\alpha$ subunit gene promoter linked to the $\beta$-galactosidase ( $\beta$-gal) (LacZ reporter) gene, and investigated to what extent the $\alpha$ subunit gene promoter enhanced LacZ gene expression. We used two models of transgenic mice expressing the nlsLacZ gene (with nuclear localization sequence) under the control of $\alpha$ AChR promoter sequences. The first, Tg1, was constructed with an 842-bp fragment and the second, Tg2, with a 3300-bp fragment of the $\alpha$ AChR promoter. In Tg1 transgenic mice ( $\alpha$ NLZ2) $\beta$-gal expression is primarily observed in developing skeletal muscle in embryonic and newborn mice (16) and at a high level in large myoid cells of the thymus of fetal and newborn mice. In the thymus of $\mathrm{Tg} 2$ mice, $\beta$-gal was observed in large myoid dispersed cells (as in $\operatorname{Tg} 1$ mice) and also in epithelial cells, especially in cortical areas. By analyzing the $T$ and $B$ cell responses against $\beta$-gal, we found that the different pattern of LacZ gene expression in the thymus of the two mouse lines conferred a distinct state of tolerance towards the transgenic protein as a self-antigen. 


\section{Methods}

\section{Generation of transgenic mice}

The construct of the $\alpha 842$ NLZ2 transgene is described by Klarsfeld et al. (16). For the construction of $\mathrm{Tg} 2$ mice, an XbaI-SalI restriction fragment containing the $\alpha \mathrm{AChR} 3.3$ subunit promoter sequence was excised from $\mathrm{p} \alpha \mathrm{ACh} 3.3 \mathrm{CAT}$ (17), and inserted into XbaI-SalI sites of pKSnlsLACZ (16). The NotI-KpnI restriction fragment was excised from $p \alpha 3.3 n l s L A C Z$, obtained and purified by using the Gene-Clean II system (Bio 101, La Jolla, CA). The DNA suspension, diluted to $\sim 3 \mu \mathrm{g} / \mathrm{ml}$ in TE buffer (Tris $10 \mathrm{mM}$, EDTA $0.5 \mathrm{mM}$ ), was injected into the pronuclei of one-cell embryos as described previously (18). The recipient mouse strain was $\mathrm{C} 57 \mathrm{~B} 16 \times \mathrm{SJL} / \mathrm{J}$ F1. Two $\beta$-gal-expressing males were obtained, and two independent lines of transgenic mice ( $\alpha 3.3$ NLZ4-14 and $\alpha 3.3$ NLZ4-7) have been established by successive backcrosses with C57B16 animals.

\section{Preparation of probes}

LacZ DNA probes. The AatII restriction fragment of LacZ gene DNA was used to hybridize Southern blot filters or RNA dot-blot filters. DNA probes were labeled by the Multiprime method (Amersham Corp., Arlington Heights, IL) with $\left[{ }^{32} \mathrm{P}\right] \mathrm{dCTP}$.

$\alpha$ RNA probe. The cDNA of the mouse AChR $\alpha$ subunit gene (a gift from J. Merlie, St. Louis, France) was used to create antisense riboprobes with $\left[{ }^{32} \mathrm{P}\right] \mathrm{UTP}$ as the incorporated radionucleotide (Promega Corp., Madison, WI). The $\alpha$ riboprobe was hybridized to RNA dotblot filters $\left({ }^{32} \mathrm{P}\right.$ probe $)$.

Oligonucleotide probes. $3^{\prime}$ tailing oligoprobes were labeled with $\left[{ }^{33} \mathrm{P}\right] \mathrm{dATP}$. A 21-mer antisense oligonucleotide of the $\alpha$ subunit gene was chosen from the 4 th and 5th exons (-5'GTCTGCGTTGTTATAGAGAAC). The antisense LacZ oligo was -5'GATGGGCGCATCGTAACCGTGC. A sense oligoprobe was chosen from LacZ sequence (-5'GTCGTTTTACAACGTCGTGACT). The LacZ gene oligonucleotides were also used as primers to detect transgenic mice by PCR (not shown).

\section{Isolation of RNA}

Thymuses of embryonic and newborn mice were quickly dissected and frozen in liquid nitrogen, then stored at $-80^{\circ} \mathrm{C}$ or used immediately. Total RNA was prepared with the RNAZOL ${ }^{\mathrm{TM}}$ system (Bioprobe, Bobigny, France).

\section{RNA dot-blot experiments}

RNA was analyzed by the dot-blot method using a manifold filtration system with Hybond-N filters. After ultraviolet fixation of RNA on the membranes for $5 \mathrm{~min}$, hybridization was done with the ${ }^{32} \mathrm{P}-\alpha$ riboprobe or ${ }^{32} \mathrm{P}-\mathrm{lacZ}$ probe in buffer containing $50 \%$ formamide, $4 \times$ SSC, $1 \times$ Denhardt's, $10 \%$ dextran sulfate, $0.5 \%$ SDS, and $20 \mu \mathrm{g} / \mathrm{ml}$ salmon sperm DNA. After overnight incubation at $50^{\circ} \mathrm{C}$ the membranes were washed in $2 \times \mathrm{SSC}$ at $60^{\circ} \mathrm{C}$ for $30 \mathrm{~min}$, then in $1 \times \mathrm{SSC}$, $0.5 \%$ SDS, and in $0.1 \times$ SSC, $0.5 \%$ SDS for various times. Filters were then autoradiographed with an intensifying screen at $-80^{\circ} \mathrm{C}$.

\section{Preparation of thymus}

Thymuses were quickly dissected from embryonic and newborn mice and fixed in freshly prepared $4 \%$ paraformaldehyde in PBS, pH 7.5, for $10-15 \mathrm{~min}$ at room temperature. Thymuses were then used immediately for the detection of $\beta$-gal activity or were stored in toto or as $10-14-\mu \mathrm{m}$ cryosections on Superfrost ${ }^{+}$slides (Poly-Labo Block, Strasbourg, France) at $-80^{\circ} \mathrm{C}$.

\section{Detection of $\beta$-gal activity}

Thymuses were incubated for $3-4 \mathrm{~h}$ at $37^{\circ} \mathrm{C}$ in a solution containing $40 \%$ X-GAL (5-bromo-4-chloro-3-indol- $\beta$-D-galactosidase), $5 \mathrm{mM}$ $\left.\mathrm{K}_{4} \mathrm{Fe}(\mathrm{CN})_{6}, 5 \mathrm{mM} \mathrm{K} \mathrm{Ke}_{3} \mathrm{FeN}\right)_{3}$, and $2 \mathrm{mM} \mathrm{MgCl}_{2}$ in PBS; the blue color often intensified after longer incubation (overnight at room temperature).

\section{Quantification of $\beta$-gal protein}

The $\beta$-gal ELISA kit (Boehringer Mannheim, Mannheim, Germany) was used to quantify $\beta$-gal protein in the organs of the transgenic mice. Briefly, thymus, muscle, spleen, and lymph nodes were dissected on postnatal days 3-6 (PN3-6) and at $8 \mathrm{wk}$. Tissue extracts were prepared in lysing buffer. The protein concentration was determined according to Bradford (19) and adjusted to $250 \mu \mathrm{g} / \mathrm{ml}$. $\beta$-gal was then measured with an ELISA method according to the manufacturer's recommendations. The detection limit was $40 \mathrm{pg} / \mathrm{ml}$.

\section{In situ hybridization with ${ }^{33} \mathrm{P}$ oligoprobe; analysis by micro- or} radioimager high resolution (RIHR)

Thymus sections were postfixed in $4 \%$ PFA in PBS for $10 \mathrm{~min}$. The hybridization buffer was freshly prepared and contained $50 \%$ formamide, $1 \times$ Denhardt's, $4 \times$ SSC, $100 \mathrm{mM}$ DTT, and 10\% dextran sulfate, with yeast tRNA, polyA, and salmon sperm DNA at $250 \mu \mathrm{g} / \mathrm{ml}$. Sections were incubated with a suspension of ${ }^{33} \mathrm{P}$ oligoprobe in hybridization buffer ( $0.2 \mathrm{pmol}$ of probe in $50 \mathrm{ml}$ of buffer per section) at $40^{\circ} \mathrm{C}$ overnight in a humid atmosphere. Sections were then washed twice in $1 \times \mathrm{SSC}, 100 \mathrm{mM}$ DTT at $55^{\circ} \mathrm{C}$; twice in $0.5 \times \mathrm{SSC}, 100 \mathrm{mM}$ DTT, and once in $0.1 \times$ SSC, $100 \mathrm{mM}$ DTT at room temperature (repeated as necessary). Finally, sections were rinsed in water and dehydrated in $96 \%$ ethanol. Radioactivity in thymus sections was measured using a $\beta$-imaging apparatus, followed by quantification and location with an RIHR device adapted from Dr. Charpak's first apparatus $(20,21)$.

\section{Immunofluorescence}

Unfixed 4- $\mu \mathrm{m}$-thick frozen thymic sections were incubated with rabbit polyclonal anti- $\beta$-gal antibody (Organon Teknika-Cappel, Durham, NC) and mouse monoclonal antikeratin (DAKO Corp., Carpinteria, CA) or antidesmin (Organon Teknika-Cappel) antibodies for $60 \mathrm{~min}$, followed by three washes in PBS. A mixture of two IgG1 antikeratin antibodies were used (MNF116 and LP34 clones; DAKO Corp.). MNF116 monoclonal antibody reacts with most TEC, particularly in the cortical region, whereas LP34 reacts with epithelial cells in the medullary region. The sections were then incubated with GARTRITC (goat anti-mouse immunoglobulin bound to tetramethylrhodamine isothiocyanate) (Immunotech, Marseille, France) and RAM IgG1 FITC (rat anti-mouse immunoglobulin bound to fluorescein isothiocyanate) (Serotec Ltd., Kidlington, Oxford, United Kingdom) at optimal concentrations for $30 \mathrm{~min}$, followed by three washes in PBS, then mounted under coverslips with glycerol/PBS. Control sections were incubated with the fluorescent conjugates.

\section{Antibody responses}

Mice were immunized intraperitoneally with $50 \mu \mathrm{g}$ of $\beta$-gal (Boehringer Mannheim) or $50 \mu \mathrm{g}$ of Torpedo AChR (a gift from Dr. J.L. Eisele, Pater Institute) in CFA. Blood was collected from the orbital sinus on days $0,10,20,30,36,48,65,90$, and 120 . To obtain a doseresponse curve, mice were immunized intraperitoneally with 20,50 , or $100 \mu \mathrm{g} / \mathrm{ml} \beta$-gal in CFA and blood was collected on days $0,20,36,43$, 64 , and 82 . Three or four transgenic and control mice were tested at each time point. Sera were tested for anti- $\beta$-gal antibodies in a standard ELISA method. Briefly, plates were coated $(5 \mu \mathrm{g} /$ well $)$ with $\beta$-gal (Boehringer Mannheim) and blocked with $2 \%$ BSA. Serial dilutions of sera were tested. Plates were developed with goat antimouse IgG-horseradish peroxidase (Jackson ImmunoResearch Labs, Inc., West Grove, PA) or with rat anti-IgG1 (Serotec Ltd.) or antiIgG2a (Serotec Ltd.) monoclonal antibodies as indicated in the text, and $o$-phenyl-diamine (Sigma Chemical Co., St. Louis, MO). The anti$\beta$-gal antibody titer was estimated from a standard curve using serial dilutions of monoclonal anti- $\beta$-gal antibody (Boehringer Mannheim).

Anti-AChR titers in the serum of immunized mice were determined by the immunoprecipitation method using purified Torpedo AChR coupled to ${ }^{125} \mathrm{I} \alpha$-bungarotoxin (22). 


\section{Proliferation assay}

Mice were immunized subcutaneously with $50 \mu \mathrm{g}$ of $\beta$-gal in CFA. $8 \mathrm{~d}$ later lymph node cells were cultured in triplicate in 96-well flat-bottomed plates in RPMI 1640 medium (GIBCO BRL, Gaithersburg, MD) supplemented with $10 \%$ FCS, 100 IU penicillin, $100 \mu \mathrm{g} / \mathrm{ml}$ streptomycin, $2 \mathrm{mM}$ L-glutamine, $25 \mathrm{mM}$ Hepes, and $5 \times 10^{-5} \mathrm{M}$ $\beta$-mercaptoethanol. Wells containing $2 \times 10^{5}$ cells and serial dilutions of $\beta$-gal or medium alone were incubated at $37^{\circ} \mathrm{C}$ for $5 \mathrm{~d}$ and pulsed with $2 \mu \mathrm{Ci}$ of $\left[{ }^{3} \mathrm{H}\right]$ thymidine for $20 \mathrm{~h}$. Plates were harvested and counted on a $\beta$ scintillation counter. To determine whether IL-2 could reverse $\beta$-gal unresponsiveness, $5 \mathrm{U}$ of rIL-2 (Boehringer Mannheim) was added per well in the $\beta$-gal proliferation assay.
Cytokine ELISA

Cytokines (IL-4 and IFN- $\gamma$ ) were detected at $72 \mathrm{~h}$ in culture supernatants by ELISA. Commercially available kits were used (Genzyme, Cambridge, MA).

\section{Results}

\section{Characterization of the transgenic mouse lineages}

Several lineages of transgenic mice were obtained with DNA constructs containing the nlsLacZ gene under the control of the chicken $\alpha$ AChR subunit promoter fragments. Tg1

\section{A Tg1}

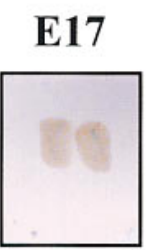

\section{E18}

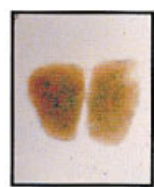

PN4

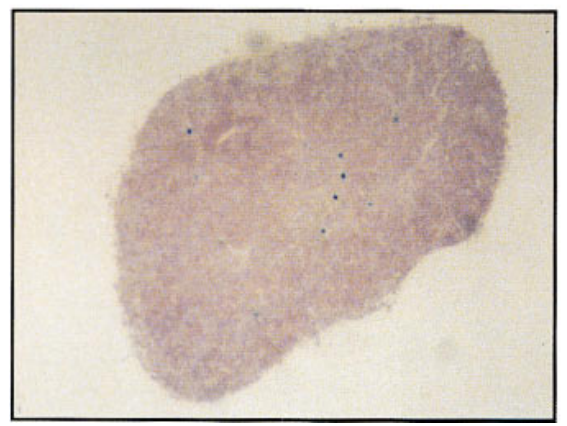

PN3

B Tg2

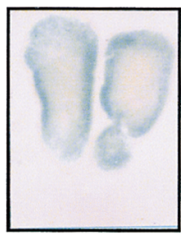

\section{PN4}

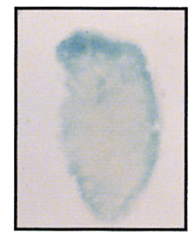

PN4 thick section

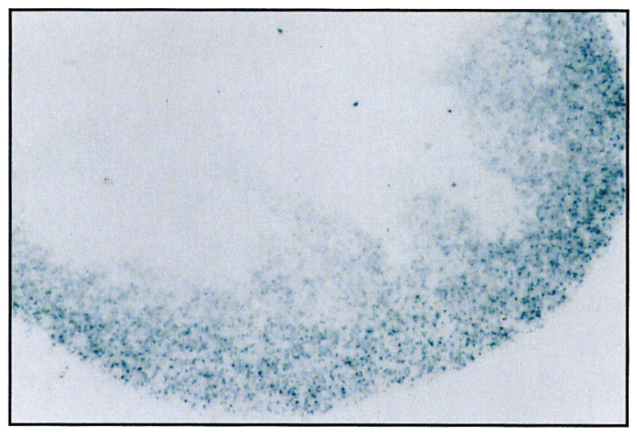

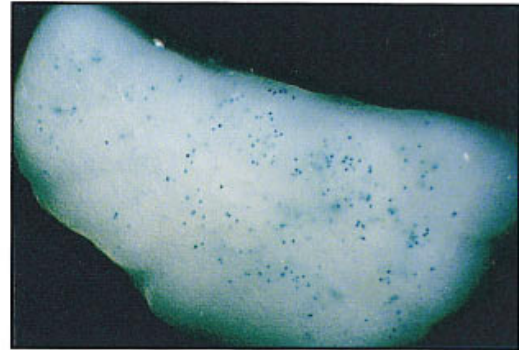

\section{PN4}

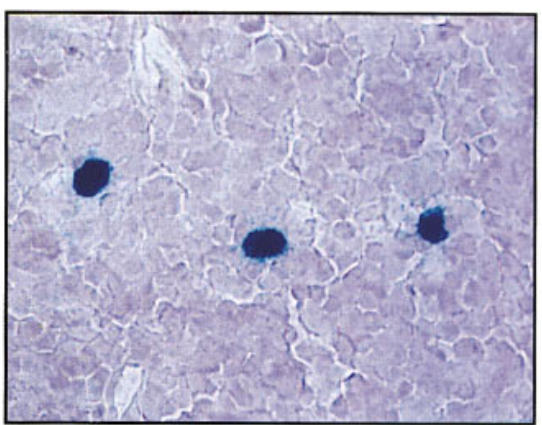

PN5

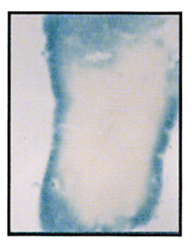

PN4 thin section

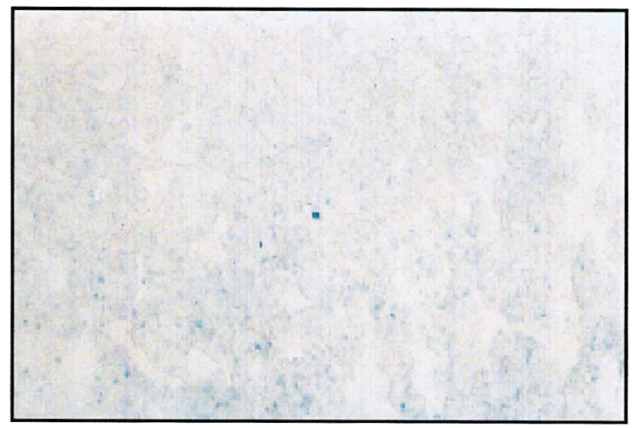

Figure 1. Thymic $\beta$-gal expression during development of $\mathrm{Tg} 1$ $(A)$ and $\operatorname{Tg} 2(B)$ mice. $(A)$ In Tg1 mice, $\beta$-gal expression (blue) is found in scattered thymic cells from E17 and persists until PN2-4. The E17, E18, and E19 thymuses are represented in toto $(\times 10)$. The scattered blue cells are visible on E19 in thick sections $(\times 60)$, whereas only a few positive cells persist in thin sections on PN4 $(\times 100$ and $\times 600$ ). (B) In Tg2 mice, blue staining is found in cortical areas on PN3-5 (thick sections, $\times 10$ and $\times 80$ ). A thin section is shown at PN4 and shows that staining in myoid cells is higher than in the cortical cells $(\times 120)$. 
( R $\alpha$ NLZ2) lines bearing a construct with a short promoter (842 bp) were generated first. As described by Klarsfeld et al. (16) and Salmon and Changeux (23), the $\alpha 842$ promoter sequence confers a spatiotemporal $\beta$-gal expression which closely parallels that of the endogenous embryonic gene. Other lines were established with a transgene containing a longer promoter sequence of the $\alpha$ subunit gene (3300 bp) derived from the chicken $\alpha$ subunit gene cloned by Klarsfeld et al.
(24). Two founder mice, selected by DNA PCR and $\beta$-gal expression in tail muscle at birth, showed stable integration of the $\alpha 3.3$ nlsLacZ transgene and are referred to as $\mathrm{Tg} 2$ mice.

The copy number of the transgene was roughly the same (about three copies) in $\alpha 842$ NLZ2- 8 (Tg1) and $\alpha 3.3$ NLZ4-14 (Tg2) mice. $\beta$-gal was mainly expressed in muscle and appeared similar in embryonic muscles in the $\operatorname{Tg} 2$ and $\operatorname{Tg} 1$ lines. Muscle staining intensity fell after birth, but $\beta$-gal expression,
PN12
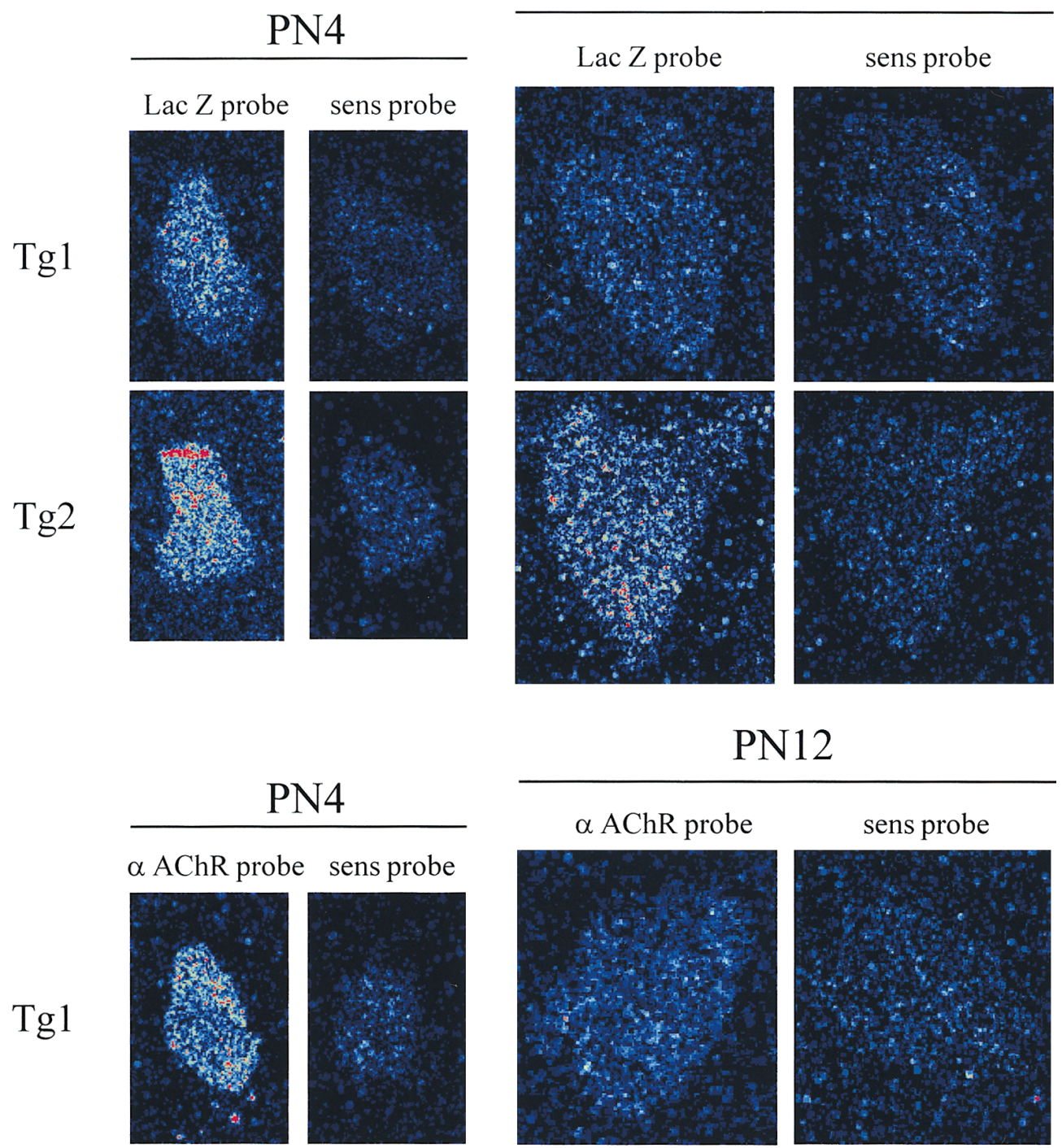

$\operatorname{Tg} 1$

$\operatorname{Tg} 2$

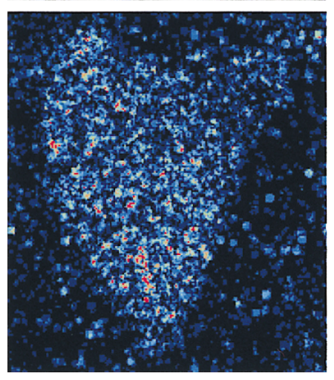

\section{PN12}
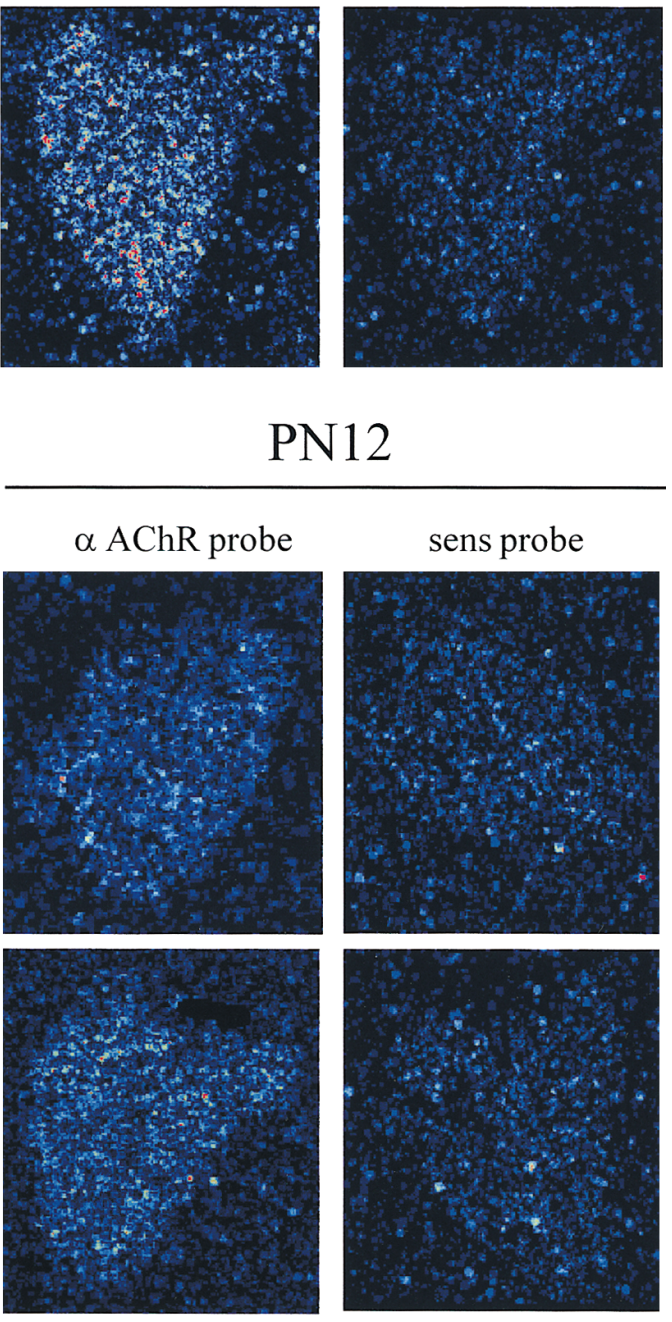
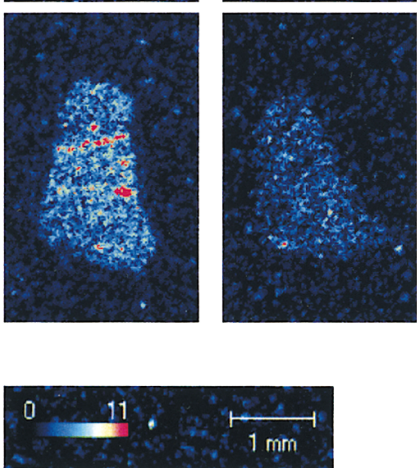

Figure 2. Microimaging of $\beta$-gal and $\alpha$ AChR mRNA in thymic sections from $\mathrm{Tg} 1$ and $\mathrm{Tg} 2$ mice. (A) The level of LacZ mRNA is higher in $\operatorname{Tg} 2$ mice than in $\operatorname{Tg} 1$ mice on PN4 and 12. (B) $\alpha$ AChR mRNA expression was similar in $\operatorname{Tg} 1$ and $\operatorname{Tg} 2$ mice. Controls with sense probes were negative. 
analyzed in leg muscles and diaphragm, remained positive until adulthood in $\mathrm{Tg} 2$, but not in $\mathrm{Tg} 1$ mice. Stronger transient synaptic expression was noted in several fast muscles in both $\mathrm{Tg} 2$ and $\mathrm{Tg} 1$ mice (23), and was also clearly observed (not shown) in a slow muscle (soleus) of $\mathrm{Tg} 2$ mice. Altogether, these observations suggest that the distribution of $\beta$-gal expression in the muscle was closer to endogenous $\alpha$ expression in $\mathrm{Tg} 2$ than in $\mathrm{Tg} 1$ mice.

\section{Kinetics of thymic $\beta$-gal expression}

In Tg1 mice $\beta$-gal expression was first detected in a few thymic cells by embryonic day 17 (E17). The number of stained cells increased on E18 and E19, then fell after birth and disappeared by PN3-4. These cells were large, scattered throughout the thymus, and strongly expressed the $\beta$-gal reporter gene (Fig. $1 A$ ). A faint diffuse staining was also observed throughout the different thymus regions (Fig. $1 A$ ). Although the LacZ gene was strongly expressed in single thymic cells of embryonic and newborn mice of both transgenic lines, the transgene was also expressed in cortical areas soon after birth in $\mathrm{Tg} 2$ mice (Fig. $1 \mathrm{~B}$ ). Many cortical cells expressed $\beta$-gal, but more weakly than in single large cells, as shown in thin sections of the thymus (Fig. $1 B$ ). This $\beta$-gal expression persisted after birth, sometimes until adulthood.

In parallel, the expression of the endogenous $\alpha$ subunit gene was explored in thymic sections by in situ hybridization with ${ }^{33} \mathrm{P}$ oligonucleotide probes. The sections were analyzed and radioactivity was quantified using a microimager. During the first days after birth, $\alpha$ subunit mRNA was observed throughout the thymus at about the same level in Tg1 and Tg2 mice (Figs. 2 and 3). LacZ mRNA expression was also analyzed in the two lineages, using the same technology. As shown in Figs. 2 and 3, LacZ mRNA levels were higher in $\mathrm{Tg} 2$ than in Tg1 mice. In addition, the LacZ mRNA level fell after PN4, as did $\alpha$ subunit mRNA (Fig. 3). Dot-blot analysis of thymic mRNA confirmed that from the day of birth, LacZ gene expression was much lower in $\mathrm{Tg} 1$ than in $\mathrm{Tg} 2$ mice (Fig. 4). Finally, the kinetics of LacZ and $\alpha$ subunit AChR gene expression ran parallel in $\mathrm{Tg} 2$ mice until adult development,

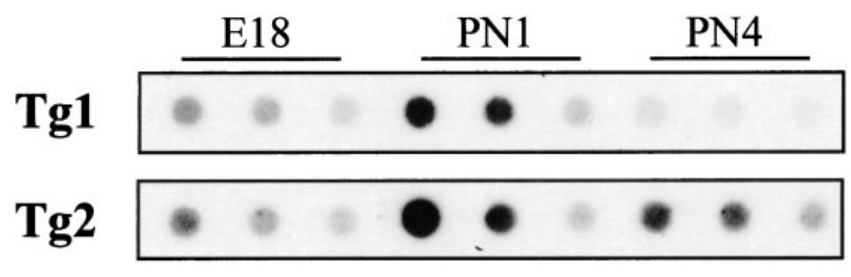

Figure 4. Dot-blot analysis of Lac-Z mRNA. Three consecutive dilutions ( $1,0.5$, and $0.25 \mu \mathrm{g}$ of RNA) were used from the thymus of $\mathrm{Tg} 1$ and Tg2 mice at E18, PN1, and PN4. Difference of expression is not visible at day 18, while at PN1 and PN4, a greater expression of Lac-Z is observed in the $\mathrm{Tg} 2$ line compared with the $\mathrm{Tg} 1$ line.

suggesting that $\beta$-gal expression in the thymus was closer to endogenous $\alpha$ expression in $\operatorname{Tg} 2$ than in $\mathrm{Tg} 1$ mice (Fig. 3).

\section{Characterization of $\beta$-gal-expressing cells}

In $\mathrm{Tg} 1$ mice, $\beta$-gal was expressed in a few cells scattered throughout the thymic sections (Fig. 5). $\beta$-gal-positive cells were labeled with an antidesmin antibody, demonstrating their myoid nature (Fig. 5). Controls (fluorescent antibodies) were consistently negative (Fig. 5). In Tg2 mice, in addition to myoid cells numerous cells were stained which were located mainly in the cortical area. To explore the nature of these $\beta$-gal-positive cells we used a mixture of two antikeratin antibodies to identify epithelial cells (Fig. 5). At a higher magnification, in the cortex double staining with the antikeratin antibodies showed that most $\beta$-gal-positive cells displayed the epithelial phenotype (Fig. 5). In the medulla, we could demonstrate that some epithelial cells express the $\beta$-gal antigen (Fig. 5). Conjugate controls were consistently negative (not shown).

Thus, both the thymic cortex and medulla of Tg2 mice expressed $\beta$-gal in immunofluorescence and in situ hybridization experiments. However, staining was more limited in the medulla than in the cortex. Since the staining by the X-gal reaction was not visible in the medulla (Fig. $1 B$ ), it is possible that the X-gal reaction had a lower sensitivity compared with the

\section{Lac-Z probe}

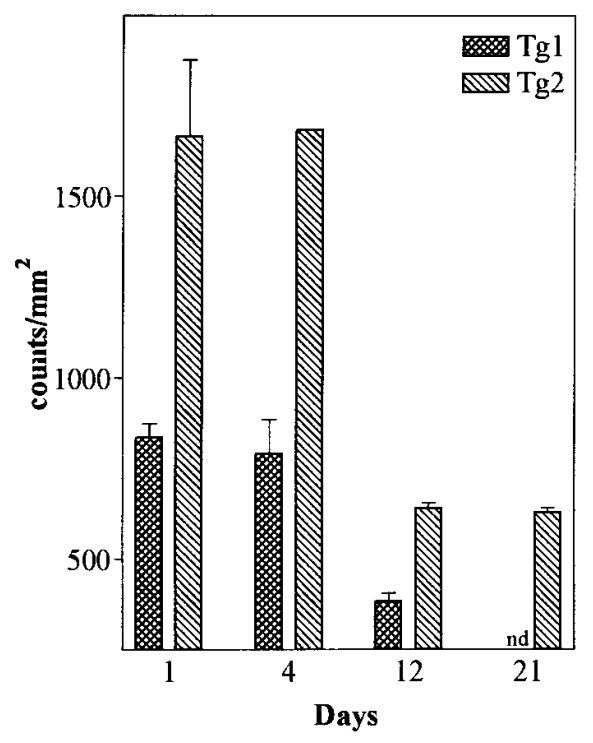

$\alpha$-AchR probe

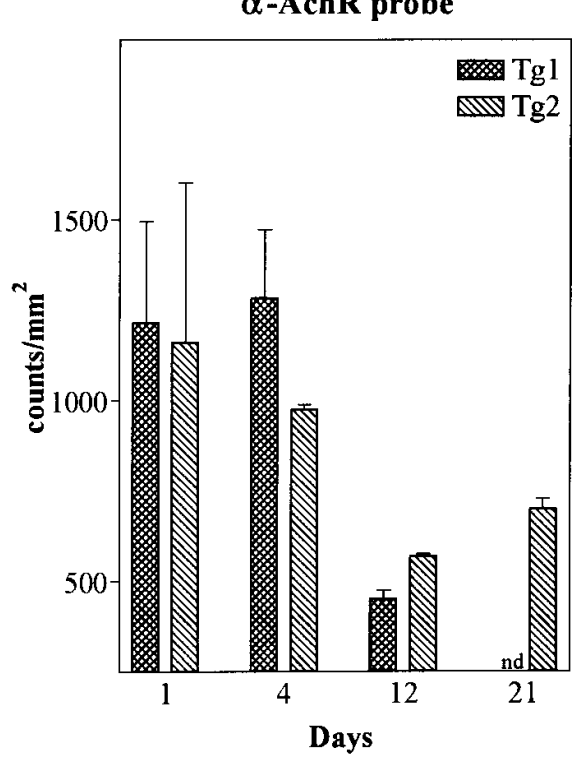

Figure 3. Quantitative analysis of $\beta$-gal and $\alpha$ AChR mRNA from thymic tissue. The results are expressed as the mean of two to six values (counts $/ \mathrm{mm}^{2}$ ) and the bar represents SEM. The levels of LacZ and $\alpha$ AChR mRNA in Tg2 mice are maximal between days 1 and 4 , and then fall in parallel. In Tg1 mice, the LacZ mRNA level is much lower than in $\mathrm{Tg} 2$ mice. Radioactivity in control Lac-Z sense probe sections was for $\mathrm{Tg} 1 \mathrm{475}, 410$, and 380 counts $/ \mathrm{mm}^{2}$ for days 1,4 , and 12 , respectively, and for $\mathrm{Tg} 2,468,488,352$, and 362 counts $/ \mathrm{mm}^{2}$ for days $1,4,12$, and 21 , respectively. 


\section{Tg1 mouse}

anti- $\beta g a l$

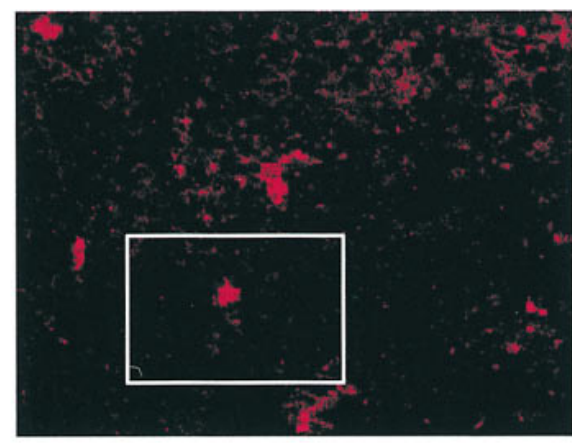

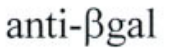

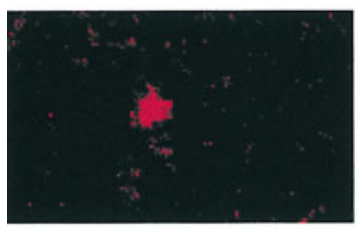

GAR -TRITC

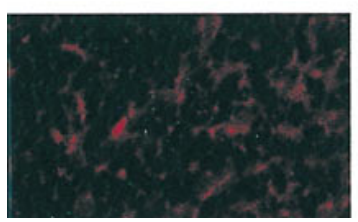

anti-desmin

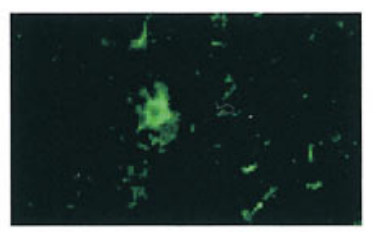

RAM -FITC

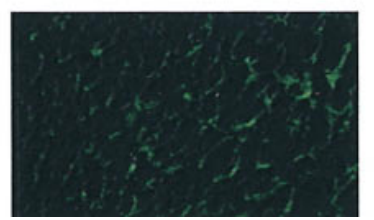

\section{Tg2 mouse}

anti- $\beta g a l$
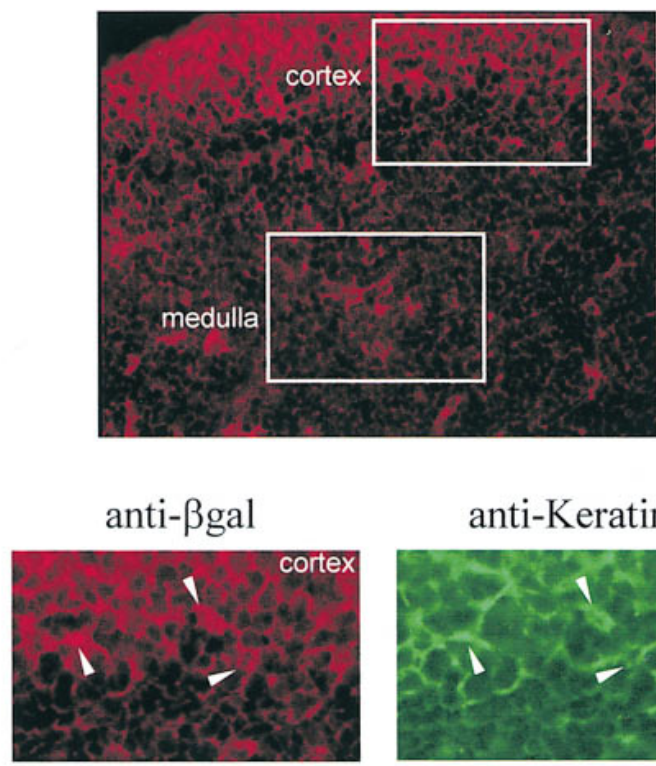

anti-Keratin
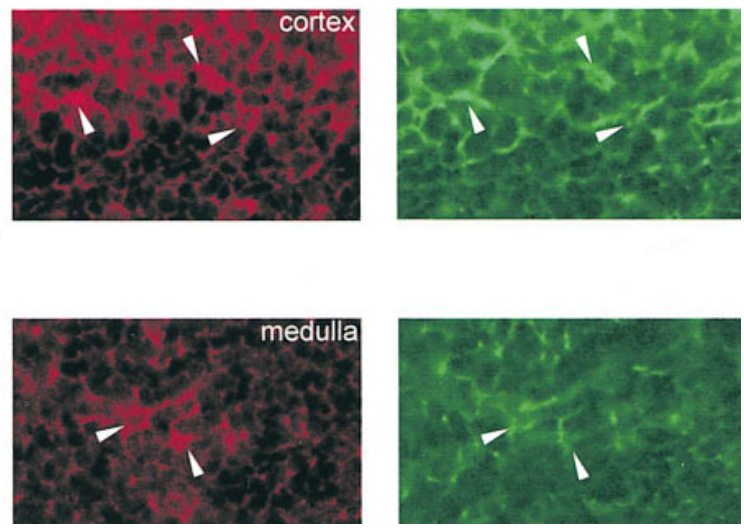

Figure 5. Characterization of $\beta$-gal-expressing cells in $\mathrm{Tg} 1$ and $\mathrm{Tg} 2$ mice. $\operatorname{In} \mathrm{Tg} 1$ mice $\beta$-gal-expressing cells are essentially found in the medulla $(\times 140)$. $\beta$-gal-expressing cells were double-stained by antidesmin antibodies $(\times 200)$. In Tg2 mice, $\beta$-gal-expressing cells are much more numerous $(\times 120)$. At a higher magnification, in the cortex, many epithelial cells are stained with anti- $\beta$-gal antibody, in the medulla, some $\beta$-gal-positive cells are epithelial cells $(\times 180)$. Controls (fluorescent antibodies) were consistently negative $(\times 200)$.

immunofluorescence staining or had a high threshold, so that the faint cells were not visible.

\section{Quantification of $\beta$-gal protein in the thymus of Tg1 and Tg2 mice}

As thymic differentiation is a dynamic process and as selection is probably the result of numerous cell interactions, we postulated that the total amount of $\beta$-gal expression was important for tolerance induction. To measure total $\beta$-gal protein expression in the thymus and peripheral lymphoid organs of Tg1 and Tg2 mice we extracted total protein and applied a $\beta$-gal ELISA method. As shown in Table I, we confirmed that only the thymus and muscle expressed $\beta$-gal. Secondary lymphoid organs (lymph nodes and spleen) and serum were consistently negative. Thymic expression was about 20 times lower in $\mathrm{Tg} 1$ than in Tg2 mice. Expression was much higher in neonates than in adult mice, confirming mRNA studies. At 8 wk $\beta$-gal could not be detected in the thymus of $\mathrm{Tg} 1$ mice, but was still faintly detected in $\mathrm{Tg} 2$ mice.

\section{Anti- $\beta$-gal antibody response in Tg mice}

KINETICS OF THE ANTIBODY RESPONSE

The anti- $\beta$-gal antibody response was investigated after immunizing Tg1 and Tg2 mice with $\beta$-gal, by comparison with nontransgenic control mice. Serum was collected from the day of immunization until $120 \mathrm{~d}$ after immunization (nine different time points). The ability to produce specific anti- $\beta$-gal antibodies was assessed by an ELISA method (Fig. $6 A$ ). Tg1 mice showed a significant specific response to $\beta$-gal, which was significantly weaker than that of nontransgenic control mice $(P<$ 0.0001 , ANOVA). By contrast, the response was clearly impaired in Tg2 mice $(P<0.0001$ compared with Tg1 and nontransgenic control mice, ANOVA). The mean maximal responses were 874,35 , and $1187 \mu \mathrm{g} / \mathrm{ml}$ in $\mathrm{Tg} 1, \mathrm{Tg} 2$, and control mice, respectively. In $\mathrm{Tg} 2$ mice the mean anti- $\beta$-gal antibody titer was therefore 34 times lower than in the control group. Torpedo AChR was used as a control antigen, and anti-AChR antibodies were analyzed by radioimmunoassay. The three mouse lines responded very similarly, indicating that these mouse lines present the same ability to produce antibodies upon immunization (Fig. $6 \mathrm{~B}$ ).

\section{DOSE-RESPONSE ANALYSIS}

In another experiment $\mathrm{Tg} 1, \mathrm{Tg} 2$, and control mice were immunized with various amounts of $\beta$-gal $(20-100 \mu \mathrm{g} / \mathrm{ml})$ and the specific anti- $\beta$-gal antibody titers were measured by ELISA on days $20,43,64$, and 82 . Similar results were obtained at the 
Table I. Concentration of $\beta$-gal in the Different Organs of Tg1 and Tg2 Mice Measured by ELISA

\begin{tabular}{|c|c|c|c|c|}
\hline & \multicolumn{4}{|c|}{$\beta$-gal $(\mathrm{pg} / \mathrm{ml})$} \\
\hline & \multicolumn{2}{|c|}{$\operatorname{Tg} 1$ mice } & \multicolumn{2}{|c|}{$\mathrm{Tg} 2$ mice } \\
\hline & $3-6 \mathrm{~d}$ & $8 \mathrm{wk}$ & $3-6 d$ & $8 \mathrm{wk}$ \\
\hline Thymus & 56 & $<40$ & 975 & 90 \\
\hline Spleen & $<40$ & $<40$ & $<40$ & $<40$ \\
\hline \multicolumn{5}{|l|}{ Lymph nodes } \\
\hline paraortic & nd & $<40$ & nd & $<40$ \\
\hline mesenteric & $<40$ & $<40$ & $<40$ & $<40$ \\
\hline inguinal & nd & $<40$ & nd & $<40$ \\
\hline Serum & $<40$ & $<40$ & $<40$ & $<40$ \\
\hline Muscle & 1505 & $<40$ & 1103 & 162 \\
\hline
\end{tabular}

Only the muscle and the thymus contain $\beta$-gal at significant levels in both $\mathrm{Tg} 1$ and $\mathrm{Tg} 2$ mice at $3-6 \mathrm{~d}$ after birth. In 8 -wk-old mice, $\beta$-gal is detectable only in $\mathrm{Tg} 2$ mice.

different time points; and those on day 64 are shown in Fig. 7. Whatever the immunizing dose, the anti- $\beta$-gal antibody response was much weaker in $\mathrm{Tg} 2$ mice than in $\mathrm{Tg} 1$ mice $(P<$ 0.0001 , ANOVA test $)$ and in control mice $(P<0.0001$, ANOVA). Although the absolute anti- $\beta$-gal antibody titer was lower in this experiment than in that shown in Fig. $6 A$, the percentage response of $\mathrm{Tg} 1$ mice was very similar in the two experiments (62 and $74 \%$, respectively, for the same $\beta$-gal dose). Whatever the immunizing dose used, the percentage response in $\mathrm{Tg} 2$ mice was below $5 \%$ of control values.

\section{ANALYSIS OF THI/TH2 RESPONSES IN TGI AND TG2 MICE}

Isotypes of anti- $\beta$-gal antibodies. To determine whether the reduced Ig response was Th1- or Th2-dependent, we analyzed the isotypes of the $\beta$-gal antibodies by using rat anti-IgG1 or anti-IgG2a in the development step of the ELISA. Fig. $8 \mathrm{~A}$ clearly shows that the anti- $\beta$-gal response was essentially Th2dependent. Indeed, the level of the $\mathrm{IgG} 2 \mathrm{a}$ isotype was very low in both the controls and the transgenic mice. The Th2-dependent $\mathrm{IgG} 1$ isotype was significantly lower in $\mathrm{Tg} 1$ and $\mathrm{Tg} 2$ mice than in controls ( $~ 63 \%$ and $<3 \%$, respectively).

Cytokine profile. To further explore the Th1/Th2 response in the transgenic mice, $\mathrm{Tg} 1, \mathrm{Tg} 2$, and control mice were immunized with $\beta$-gal. $8 \mathrm{~d}$ later, lymph node cells were cultured in the presence of $\beta$-gal and supernatants were titrated for their contents in IL-4 and IFN- $\gamma$ (Fig. 8 B). Compared with cells from nontransgenic control mice, cells from $\mathrm{Tg} 1$ mice produced comparable levels of IL-4, but much lower levels of IFN- $\gamma$, whereas cells from $\mathrm{Tg} 2$ mice produced low levels of IFN- $\gamma$ and undetectable levels of IL-4 (Fig. 8 B). The calculated ratio of IL-4 to IFN- $\gamma$ was $0.5,2.6$, and 0 for control, $\mathrm{Tg} 1$, and $\mathrm{Tg} 2$ mice, respectively, underlining an imbalance in favor of $\mathrm{Th} 2$ cell type in $\mathrm{Tg} 1$ mice.

\section{Anti- $\beta$-gal proliferation assay and effect of $I L-2$}

The ability of $\mathrm{T}$ cells from immunized mice to proliferate in response to $\beta$-gal is shown in Fig. $9 \mathrm{~A}$. Cultured lymph node cells from $\mathrm{Tg} 1$ and $\mathrm{Tg} 2$ mice showed lower $\beta$-gal-dependent proliferation than controls $(P<0.0001$ for both transgenic lines, ANOVA). The results obtained in $\mathrm{Tg} 1$ mice suggested that the $\beta$-gal proliferative response was much more sensitive to tolerance induction than was anti- $\beta$-gal antibody production, as the antibody response was reduced by $\sim 30 \%$ relative to the mean control value, while antigen-specific proliferation fell by $\sim 90 \%$.

Finally, lymph node cells from $\mathrm{Tg} 1$ and $\mathrm{Tg} 2$ mice were stimulated in vitro with $\beta$-gal and exogenous rIL-2 $(25 \mathrm{U} / \mathrm{ml})$. As shown in Fig. $9 B$, IL-2 restored the proliferative response of $\mathrm{Tg} 1$ and $\mathrm{Tg} 2$ lymph node cells to $\beta$-gal, suggesting that tolerance in these mice might be induced by a mechanism of anergy. However, the possibility that tolerance is also induced by clonal deletion of specific Th cells cannot be ruled out.

\section{Discussion}

The $\alpha$ AChR promoter confers intrathymic expression in transgenic mice. Contradictory data have been published on $\mathrm{AChR}$ expression in the thymus. Since the discovery of $\alpha$-bungarotoxin binding sites in the thymus (25), there has been a vigor-

A


Figure 6. Kinetics of the primary antibody response in $\mathrm{Tg} 1$ and $\mathrm{Tg} 2$ mice. Each point is the mean for three to four mice. The bar represents SEM. The $\beta$-gal antibody response of $\mathrm{Tg} 1$ mice was slightly but significantly weaker than that of control mice, while the response of $\mathrm{Tg} 2$ mice was almost undetectable $(A)$. The primary response to Torpedo $\mathrm{AChR}$, used as a control antigen, was similar in the two transgenic mice and control mice $(B)$. 


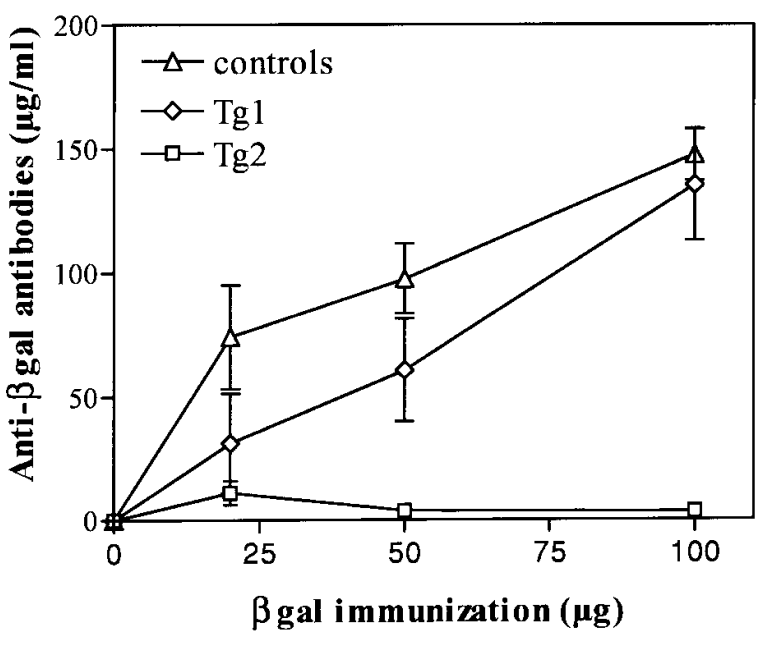

Figure 7. Dose-effect relation of the primary anti- $\beta$-gal response in $\mathrm{Tg} 1$ and $\mathrm{Tg} 2$ mice on day 64 . Each point is the mean for four mice. The bar represents SEM. The anti- $\beta$-gal response of $\operatorname{Tg} 1$ mice was slightly lower than that of control mice, while the response of $\mathrm{Tg} 2$ mice was almost undetectable, whatever the dose of $\beta$-gal injected.

ous debate as to whether or not the thymus expresses an authentic AChR or rather an AChR-like protein, and where such a protein might be located. Myoid cells and epithelial cells have been reported to express AChR-like molecules (1215, 25-28). For example, Marx et al. observed immunoreactivity with a monoclonal antibody directed against the cytoplasmic portion of the AChR both in myasthenic thymomas and in cortical epithelial cell lines derived from them (28); it was subsequently shown to be due to a non-AChR cross-reactive 153-kD protein (29). Expression of AChR genes in the thymus has been investigated by means of molecular biology. Geuder et al. did not detect AChR mRNA by Northern blot analysis (30), but Wheatley et al., using RT-PCR, detected the AChR $\alpha$ subunit mRNA in SV40-immortalized murine cortical and medullar epithelial cell lines (14). By the same method, Kaminski et al. (31) demonstrated the presence of $\alpha$ and other subunits of the muscle AChR in whole thymus preparations. More recently, the different subunits of the adult AChR were detected at the mRNA level in human TEC (15). Using transgenic mice expressing the LacZ gene under the control of the $\alpha$ AChR promoter, we obtained strong evidence that the AChR is present in two types of thymic cells: myoid cells, which are rare, dispersed throughout the thymus and show a high level of expression; and epithelial cells, which are numerous and predominantly located in the outer cortex. This expression is consistent with data from Wheatley et al. reporting $\alpha$ AChR mRNA expression in a cortical epithelial cell line (14).

Our main finding in this study is that thymic expression of the transgene differed in the two mouse lines. In the $\mathrm{Tg} 1$ model, the 842-bp promoter fragment conferred exclusive transgene expression in myoid cells, while in the $\mathrm{Tg} 2$ model the longer promoter fragment ( $3300 \mathrm{bp}$ ) also led to expression in TEC. Differences in the number of gene copies or the site of transgene insertion might explain these observations. However, the number of copies was three to four in both mouse lines, and two distinct lines were raised for each construct and yielded similar results, thus ruling out the difference in the in-
$\mathbf{A}$

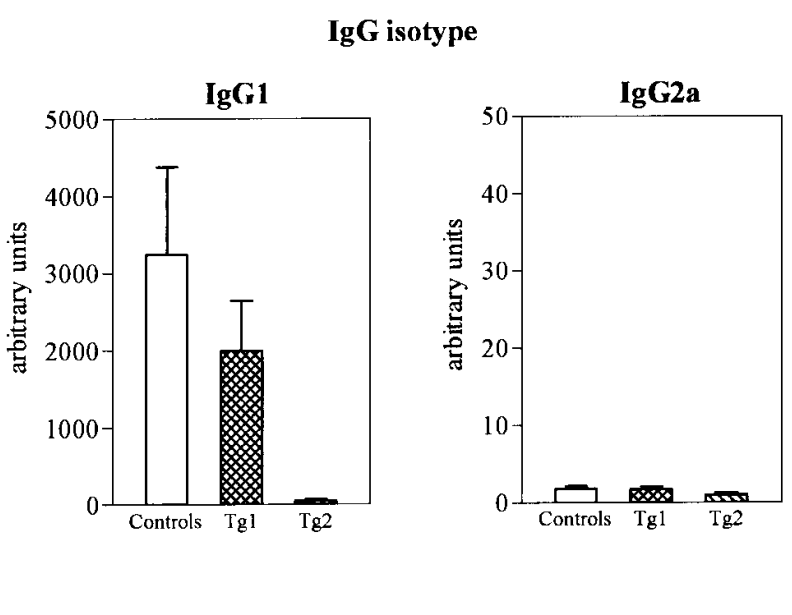

B Cytokine production
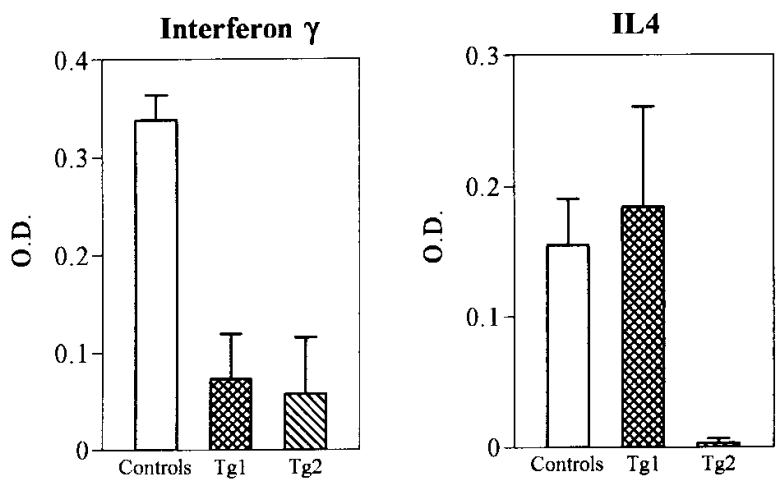

Figure 8 . Th1/Th2 response in $\operatorname{Tg} 1$ and $\operatorname{Tg} 2$ mice. $(A)$ Isotype analysis of anti- $\beta$-gal antibodies produced by $\mathrm{Tg} 1$ and $\mathrm{Tg} 2$ mice. Sera from $\beta$-gal-immunized $\mathrm{Tg} 1$ and $\mathrm{Tg} 2$ mice were collected and analyzed by ELISA for anti- $\beta$-gal antibodies of the $\mathrm{IgG} 1$ and $\mathrm{IgG} 2$ a isotypes, as described in Methods. Titers are expressed in arbitrary units (OD $\times$ serum dilution). The IgG1 titer is slightly reduced in $\mathrm{Tg} 1$ and markedly reduced in $\mathrm{Tg} 2$ relative to controls. (B) Cytokine (IL-4 and IFN- $\gamma$ ) titration in the supernatants. Stimulation by $\beta$-gal induces a significant production of IL- 4 and IFN- $\gamma$ in control mice. In Tg1, IL-4 is still detectable, whereas in $\mathrm{Tg} 2$ the cytokine production is undetectable.

sertion site. The different thymic expression is more likely due to the length of the promoter. In Tg1 mice, $842 \mathrm{bp}$ was sufficient for the expression in myoid cells, in keeping with the expression of the transgene in skeletal muscle of this transgenic line (16). The expression in other cell types (TEC) in $\mathrm{Tg} 2$ mice would require DNA elements present upstream in the $3.3-\mathrm{kb}$ fragment, which are probably activated by factors present in TEC.

Putative role of AChR in TEC. These data raise the physiological relevance of AChR expression in TEC. Peptide innervation has been suspected in the thymus (32). Acetylcholine, and other neurotransmitters, regulate functions of immunocompetent cells, mainly via enhanced proliferative responses of peripheral T cells (33). A recent report suggested that cholinergic stimulation modulated apoptosis and differentiation of murine thymocytes via a nicotinic effect on the thymic epithelium (34). Acetylcholine and carbamylcholine both enhance 


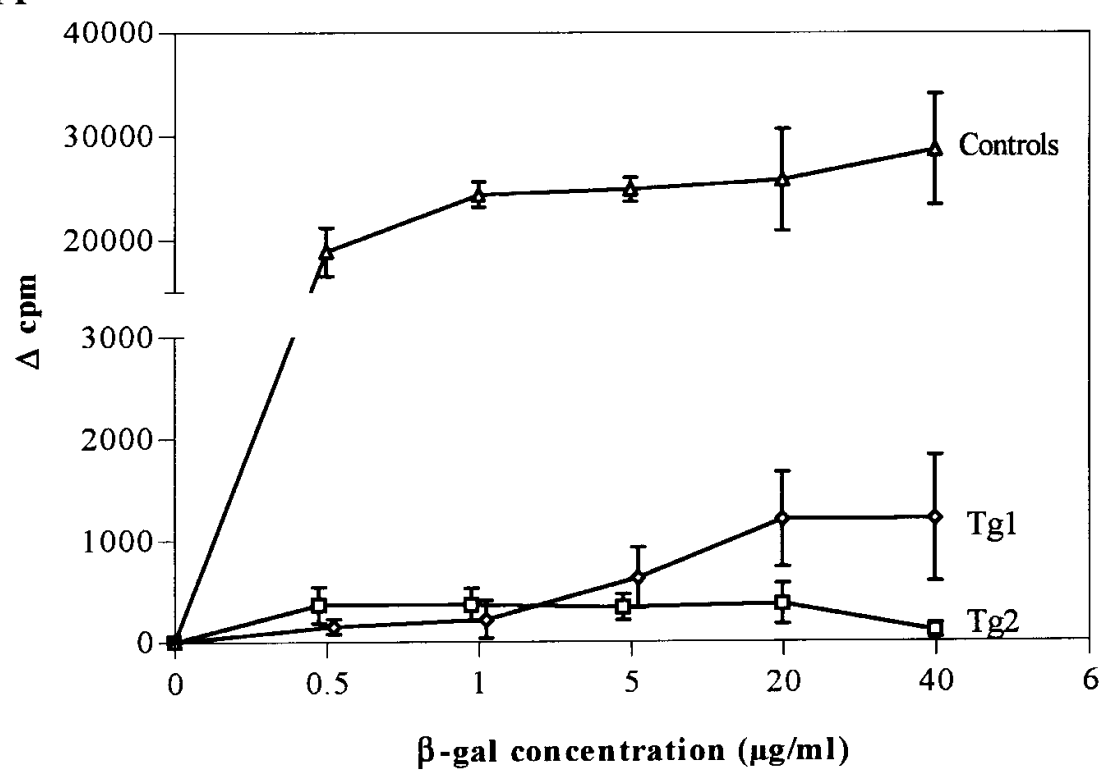

B

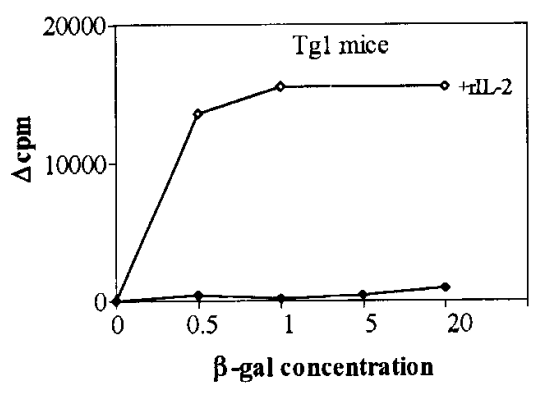

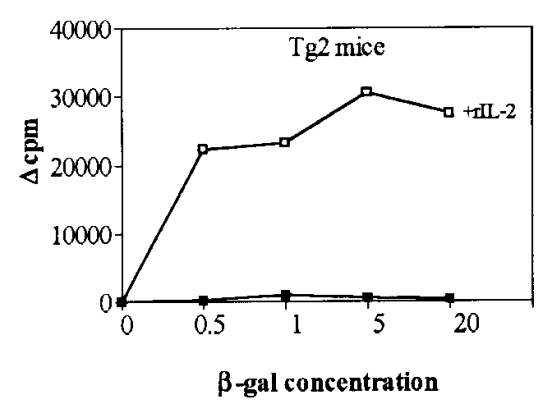

Figure 9. (A) $\beta$-gal-dependent T cell proliferation in $\operatorname{Tg} 1$ and $\mathrm{Tg} 2$ mice. Each point is the mean for three to four mice. The bar represents SEM. In Tg1 mice, T cell proliferation was very low compared with control mice, whereas in $\mathrm{Tg} 2$ mice there was no proliferation at all. Control responses to another antigen, PPD, showed similar responses: $10780 \pm 1545$ in control mice, $9850 \pm 1335$ in $\mathrm{Tg} 1$ mice, and $12670 \pm 1905$ in $\mathrm{Tg} 2$ mice. (B) Addition of rIL-2 reversed the $\beta$-gal unresponsiveness of $\mathrm{Tg} 1$ and $\mathrm{Tg} 2$ mice.
TEC proliferation in preconfluent TEC lines (35). The presence of choline acetyltransferase, which is responsible for the synthesis of acetylcholine, has been demonstrated in the thymus (36). Together with our demonstration that AChR transcription is activated in TEC, these reports suggest that cholinergic signals to TEC may regulate thymic differentiation and selection processes.

Why is $\beta$-gal not fully tolerated in Tg1 mice? Studies of the interaction of $\mathrm{T}$ cells with major histocompatibility antigens showed that the thymus is the primary site of self-tolerance induction, and that mechanisms including programmed cell death and functional inactivation eliminate self-reactive T lymphocytes (37). Tolerance induction occurs in the thymus when immature thymocytes are selected to move into the mature thymocyte pool via interactions with self-antigens $(38,39)$. Intrathymic antigen injection led to unresponsiveness to the same antigen in several experimental models $(40,41)$. In this study we examined $\mathrm{T}$ cell proliferation and antibody production in response to $\beta$-gal as a self-antigen. Both $\operatorname{Tg} 1$ and $\operatorname{Tg} 2$ mice showed reduced $\mathrm{T}$ cell proliferation, while anti- $\beta$-gal antibody production occurred only in $\mathrm{Tg} 1$ mice. This raises the question of why tolerance towards a $\mathrm{T}$ cell-dependent selfantigen fails in $\operatorname{Tg} 1$ mice, even though they express a significant level of $\beta$-gal in their thymus. Several mutually compatible explanations can be forwarded. First, myoid cells may not be able to present the antigen to developing T cells, or costim- ulatory signals may be lacking. This is unlikely, as these mice were virtually unresponsive in the T cell proliferation assay. In addition, it was suggested recently that the cell type is not important in inducing clonal deletion, as many cell types, including fibroblasts, melanoma cells, and neural cells, have this ability (42). Furthermore, even if myoid cells are unable to present the antigen, $\beta$-gal was strongly expressed in these cells, and could be released, for example, by cell death, and captured by other thymic cells, that could in turn induce cell tolerance. Second, the localization of expressing cells could be important. Indeed, in the Tg1 line the expression was limited to some isolated cells essentially in the medulla, while in the $\mathrm{Tg} 2$ line, expressing cells were found mainly in the cortex and faintly in the medulla. Third, the kinetics of antigen expression may be important. Self-tolerance is achieved mainly by the deletion and inactivation of autoreactive T cells during thymic development (37-39). In the Tg1 model, $\beta$-gal expression decreases after birth, whereas $\beta$-gal expression increases after birth and is still present in adulthood in $\mathrm{Tg} 2$ mice. Thus it is possible that the significant decrease of $\beta$-gal-expressing cells in Tg1 mice after birth is responsible for the incomplete tolerance in these mice. However, it is important to emphasize that the expression of $\beta$-gal during embryonic and neonatal periods in the Tg1 mouse line was sufficient for obtaining unresponsiveness in the proliferation assay. Thus, it is possible that the presence of antigen in adult is necessary for tolerizing Th 2 cells. Finally, 
the self-antigen is not sufficiently abundant in $\operatorname{Tg} 1$ mice to induce full tolerance. Differences in the frequency, duration, and intensity of contacts between $\mathrm{T}$ cells and the tolerating tissue are probably crucial. Limiting levels of expression of self-antigen influence the efficiency of negative selection, enabling potentially self-reactive $T$ cells to escape tolerance induction (43, 44). In $\operatorname{Tg} 1$ mice we found that total expression of $\beta$-gal was $\sim 20$ times lower than in Tg2 mice. Thus, expression in Tg1 mice may be just sufficient for $\mathrm{T}$ cell proliferation unresponsiveness, but too low to induce tolerance in terms of antibody production. Adelstein et al. (45) analyzed self-tolerance in transgenic mice expressing different serum concentrations of hen-egg lysozyme and found that $\mathrm{T}$ cells were tolerant irrespective of the antigen concentration, whereas B cell tolerance did not occur when the concentration was $<1.5 \mathrm{ng} / \mathrm{ml}$. In our study, analysis of $\beta$-gal expression in the periphery indicates that $\beta$-gal antigen levels in serum and peripheral lymphoid organs were below the detection limit $(<40 \mathrm{pg} / \mathrm{ml})$ in both mouse lines, and that transgene expression was essentially limited to muscle. The most plausible hypothesis is that peripheral tolerance does not contribute significantly to antibody unresponsiveness in $\mathrm{Tg} 2$ mice, which would rather be due to tolerance of Th2 thymic cells. A recent study in which AChR was injected into the thymus supports this hypothesis (46): lymph node cells from rats receiving intrathymic injection of AChR showed reduced proliferation to $\mathrm{AChR}$ and marked inhibition of IFN- $\gamma$ secretion, whereas antibody production was not affected, indicating that Th1 but not Th2 cells were tolerized. A Th1 $>$ Th2 $>$ B cell gradient of sensitivity to tolerance induction has been forwarded (47). The level of $\beta$-gal expression could thus be sufficient for tolerance induction of Th1 cells but not Th 2 cells in Tg1 mice, while both Th1 and Th2 populations are tolerized in $\mathrm{Tg} 2$ mice. This is supported by our finding that the anti- $\beta$-gal isotype was mainly Th2-dependent, and that the IgG1 anti- $\beta$-gal antibody titer was reduced in $\mathrm{Tg} 1$ and abrogated in $\mathrm{Tg} 2$ mice, as well as by the cytokine profile analysis. The different sensitivity to tolerance induction between Th1 and Th2 cells could be due to the nature of the epitopes involved during the challenge step (48). As $\beta$-gal is a complex molecule, it is conceivable that the low expression of $\beta$-gal in $\operatorname{Tg} 1$ mice compared with $\mathrm{Tg} 2$ mice allows only tolerance to self-dominant epitopes, while challenge with $\beta$-gal induces a response to cryptic epitopes. According to the hypothesis of Sercarz and co-workers (49), the incomplete tolerance in Tg1 mice could be due to cryptic self-transgenic epitopes that are not tolerized during the intrathymic selection process. Inefficient processing may partly be overcome by the presence of large amounts of protein, and this could explain why the same antigen is fully tolerated in $\mathrm{Tg} 2$ mice.

Implications for autoimmune diseases and $M G$. Our results show that the tolerance of developing $\mathrm{T}$ cells in the thymus is dependent on the level of expression of the self-antigen. Similar observations have been reported recently in other models of autoimmunity. In the human insulin-dependent diabetes mellitus that results from the autoimmune destruction of the insulin-producing pancreatic $\beta$ cells, the susceptibility to diabetes is higher in patients with lower insulin thymic expression, indicating that high thymic expression might prevent $\beta$ cell destruction by promoting the deletion in the thymus of insulinreactive, diabetogenic $\mathrm{T}$ cells $(50,51)$. In the experimental model of autoimmune uveoretinitis, a correlation between constitutive expression of ocular autoantigens in the thymus and resistance to autoimmunity was evidenced (52). In MG, an antibody response to the $\mathrm{AChR}$ is raised, thus indicating that thymic AChR expression levels are too low to induce tolerance. Several arguments support this hypothesis. First, immunization of mice with affinity-purified mouse AChR induces not only anti-AChR antibody responses but also myasthenic symptoms in some animals, even when AChR is injected without adjuvants (53). Second, AChR-reactive T and B cells have been reported not only in MG patients but also in controls (54). Third, the level of AChR protein has been examined in a previous report (55) that indicates that the number of $\mathrm{AChR}$ molecules is $\sim 0.9 \mathrm{fmol} / \mathrm{mg}$ of tissue, that is about 8 (adult age) and 80 (neonatal) times less than the $\beta$-gal expression detected in the Tg2 mice. Thus, even if the distribution of $\beta$-gal in $\mathrm{Tg} 2$ mice looks similar to that of the endogenous gene, a major difference in the amount of the antigen expressed could explain why an anti- $\beta$-gal response did not take place in $\mathrm{Tg} 2$ mice, while an anti-AChR response was obtained. Environmental antigens may activate $\mathrm{T}$ cells which cross-react with the autoantigen, thereby initiating autoimmunity. Thus, as in other models, autoimmunity in MG is not necessarily due to a breakdown of self-tolerance. Indeed, in transgenic mice expressing the glycoprotein of lymphocytic choriomeningitis virus (LCMVGP) under the control of the rat insulin promoter, viral glycoprotein on islet $\beta$ cells is ignored by the immune system. However, in appropriate priming conditions, an immune reaction against this antigen can be mounted and can induce autoimmunity (56).

Finally, these two transgenic mice lines are powerful tools not only for characterizing the cells potentially expressing AChR but also for exploring the mechanisms of tolerance towards an antigen differentially expressed in the thymus. These models are complementary to the recently described $\beta$-gal transgenic models showing distinct thymic $\beta$-gal expression (57). Furthermore, as the self-antigen is transiently expressed in the thymus, these models could also contribute to our understanding of how self-tolerance is maintained during aging.

\section{Acknowledgments}

We thank our colleagues J. Kanelopoulos, J.L. Bessereau, H. Nghiem, L. Marubio, and S. Brown for helpful discussion and careful reading of the manuscript.

This work was supported by grants from Centre Nationale de la Recherche Scientifique, Caisse Nationale d'Assurance Maladie des Travailleurs Salaries, Association Française contre les Myopathies, and Pasteur Institute.

\section{References}

1. Lindstrom, J.M., M.L. Seybold, V.A. Lennon, S. Whittingham, and D.D. Duane. 1976. Antibody to acetylcholine receptor in myasthenia gravis: prevalence, clinical correlates and diagnostic value. Neurology. 26:1054-1059.

2. Tzartos, S.J., M.E. Seybold, and J. Lindstrom. 1989. Specificities of antibodies to acetylcholine receptors in sera from myasthenia gravis patients measured by monoclonal antibodies. Proc. Natl. Acad. Sci. USA. 79:188-192.

3. Barkas, S., J.M. Gabriel, A. Mauron, J. Hughes, B. Roth, C. Alliod, S. Tzartos, and M. Ballivet. 1988. Monoclonal antibodies to the main immunogenic region of the nicotinic acetylcholine receptor bind to residues $61-76$ of the $\alpha$-subunit. J. Biol. Chem. 263:5916-5920.

4. Fambrough, D.M., D.B. Drachman, and S. Satyamurti. 1973. Neuromuscular junction in MG: decreased acetylcholine receptor. Science. 182:293-295.

5. Drachman, D.B. 1994. Myasthenia gravis. N. Engl. J. Med. 330:17971810.

6. Le Brigand, H., P. Levasseur, A.R. Miranda, C. Gaud, and I. Wojakowski. 1980. Surgical treatment of myasthenia gravis by thymectomy: a report 
on 248 cases. Ann. Chir. (Paris). 34:169-172.

7. Berrih-Aknin, S., E. Morel, F. Raimond, D. Safar, C. Gaud, J.P. Binet, P. Levasseur, and J.F. Bach. 1987. The role of the thymus in myasthenia gravis: immunohistological and immunological studies in 115 cases. Ann. NY Acad. Sci. 505:50-70.

8. Berrih, S., E. Morel, C. Gaud, F. Raimond, H. Le Brigand, and J.F. Bach. 1984. Anti-AChR antibodies, thymic histology, and T cell subsets in myasthenia gravis. Neurology. 34:66-71.

9. Leprince, C., S. Cohen-Kaminsky, S. Berrih-Aknin, D. Treton, P. Galanaud, and Y. Richard. 1990. Thymic B cells from myasthenia gravis patients are activated B cells: phenotypic and functional analysis. J. Immunol. 145: 2115-2122.

10. Kuks, J.B., H.J. Oosterhuis, P.C. Limburg, and T.H. The. 1991. Antiacetylcholine receptor antibodies decrease after thymectomy in patients with myasthenia gravis. Clinical correlations. J. Autoimmun. 4:197-211.

11. Schluep, M., N. Willcox, A. Vincent, G.K. Dhoot, and J. NewsomDavis. 1987. Acetylcholine receptors in human thymic myoid cells in situ: an immunohistological study. Ann. Neurol. 22:212-222.

12. Marx, A., T. Kirchner, F. Hoppe, R. O'Conner, B. Schalke, S. Tzartos, and H.K. Müller-Hermelink. 1989. Proteins with epitopes of the acetylcholine receptor in epithelial cell cultures of thymomas in myasthenia gravis. Am. J. Pathol. 134:865-877.

13. Hara, Y., S. Ueno, T. Uemichi, N. Takahashi, S. Yorifuji, Y. Fujii, and S. Tarui. 1991. Neoplastic epithelial cells express $\alpha$-subunit of muscle nicotinic acetylcholine receptor in thymomas from patients with myasthenia gravis. FEBS Lett. 279:137-140.

14. Wheatley, L.M., D. Urso, K. Tumas, J. Maltzman, E. Loh, and A.I. Levinson. 1992. Molecular evidence for the expression of nicotinic acetylcholine receptor alpha-chain in mouse thymus. J. Immunol. 148:3105-3109.

15. Wakkach, A., T. Guyon, C. Bruand, S. Tzartos, S. Cohen-Kaminsky, and S. Berrih-Aknin. 1996. Expression of acetylcholine receptor genes in human thymic epithelial cells. Implications for myasthenia gravis. J. Immunol. $157: 3752-3760$

16. Klarsfeld, A., J.L. Bessereau, A.M. Salmon, A. Triller, C. Babinet, and J.P. Changeux. 1991. An acetylcholine receptor $\alpha$-subunit promoter conferring preferential synaptic expression in muscle of transgenic mice. EMBO J. 10:625-632.

17. Piette, J., A. Klarsfeld, and J.P. Changeux. 1989. Interaction of nuclear factors with the upstream region of the $\alpha$ subunit gene of chicken muscle acetylcholine receptor: variations with muscle differentiation and denervation. EMBO (Eur. Mol. Biol. Organ.) J. 83:687-694.

18. Brinster, R.L., Y. Chen, M.E. Trumbauer, M.K. Yagle, and R.D. Palmiter. 1985. Factors affecting the efficiency of introducing foreign DNA into mice by microinjecting eggs. Proc. Natl. Acad. Sci. USA. 82:4488-4492.

19. Bradford, M.M. 1976. A rapid and sensitive method for the quantitation of microgram quantities of protein using the principle of protein-dye binding. Anal. Biochem. 72:248-254.

20. Charpak, G., W. Dominic, and N. Zaganidis. 1989. Optical imaging of the spacial distribution of beta-particles emerging from surfaces. Proc. Natl. Acad. Sci. USA. 86:1741-1745.

21. Dubois-Dauphin, M., J.M. Theler, N. Zaganidis, W. Dominik, E. Tribollet, P. Pevet, G. Charpak, and J.J. Dreiffus. 1991. Expression of vasopressin receptors in hamster hypothalamus is sexually dimorphic and dependent upon photoperiod. Proc. Natl. Acad. Sci. USA. 88:11163-11167.

22. Lindstrom, J.M., V.A. Lennon, M.E. Seybold, and S. Whittingham. 1976. Experimental autoimmune myasthenia gravis and myasthenia gravis: biochemical and immunochemical aspects. Ann. NY Acad. Sci. 274:254-274.

23. Salmon, A.M., and J.P. Changeux. 1992. Regulation of an acetylcholine receptor LacZ transgene by muscle innervation. NeuroReport. 3:973-976.

24. Klarsfeld, A., and J.P. Changeux. 1985. Activity regulates the levels of acetylcholine receptor $\alpha$-subunit mRNA in cultured chicken myotubes. Proc. Natl. Acad. Sci. USA. 82:4558-4562.

25. Engel, W.K., J.L. Trotter, D.E. McFarlin, and C.L. McIntosh. 1977. Thymic epithelial cell contains acetylcholine receptor. Lancet. 1:1310-1311.

26. Kao, I., and D.B. Drachman. 1978. Thymic muscle cells bear acetylcholine receptors: possible relation to myasthenia gravis. Science. 195:74-75.

27. Wekerle, H., U.P. Ketelson, A.D. Zurn, and B.W. Fulpius. 1978. Intrathymic pathogenesis of myasthenia gravis: transient expression of acetylcholine receptors on thymus-derived myogenic cells. Eur. J. Immunol. 8:579-582.

28. Marx, A., T. Kirchner, F. Hoppe, R. O'Conner, B. Schalke, S. Tzartos, and H.K. Müller-Hermelink. 1989. Proteins with epitopes of the acetylcholine receptor in epithelial cell cultures of thymomas in myasthenia gravis. Am. J. Pathol. 134:865-877.

29. Marx, A., R. O'Connor, K.I. Geuder, F. Hoppe, B. Schalke, S. Tzartos, I. Kalies, T. Kirchner, and H.K. Müller-Hermelink. 1990. Characterization of a protein with an acetylcholine receptor epitope from myasthenia gravis-associated thymomas. Lab. Invest. 62:279-286.

30. Geuder, K.I.R., R. Schoepfer, T. Kirchner, A. Marx, and H.K. MüllerHermelink. 1989. The gene of the $\alpha$-subunit of the acetylcholine receptor: molecular organization and transcription in myasthenia-associated thymomas. Thymus. 14:179-186.

31. Kaminski, H.J., R.A. Fenstermaker, F.W. Abdul-Karim, J. Clayman, and R.L. Ruff. 1993. Acetylcholine receptor subunit gene expression in thymic tissue. Muscle Nerve. 16:1332-1337.
32. Muller, S., and E. Weihe. 1991. Interrelation of peptidergic innervation with mast cells and ED1-positive cells in rat thymus. Brain Behav. Immun. 5: $55-72$

33. Plaut, M. 1987. Lymphocyte hormone receptors. Ann. Rev. Immunol. 5 621-669.

34. Rinner, I., T. Kukulansky, P. Felsner, E. Skreiner, A. Globerson, M Kasai, K. Hirokawa, W. Korsatko, and K. Schauenstein. 1994. Cholinergic stimulation modulates apoptosis and differentiation of murine thymocytes via a nicotinic effect on thymic epithelium. Biochem. Biophys. Res. Commun. 203:10571062

35. Tominaga, K., Y. Kinoshita, F. Hato, A. Masuda, and M. Matsuyama 1989. Effects of cholinergic agonists on the proliferation and protein synthesis in a cultured thymic epithelial cell line. Cell. Mol. Biol. 35:679-686.

36. Tria, M.A., G. Vantini, M.G. Fiori, and A. Rossi. 1992. Choline acetyltransferase activity in murine thymus. J. Neurosci. Res. 31:380-386.

37. Nossal, G.J.V. 1994. Negative selection of lymphocytes. Cell. 76:229-239.

38. Kappler, J.W., N. Roehm, and P. Marrack. 1987. T cell tolerance by clonal elimination in the thymus. Cell. 49:273-280.

39. Kisielow, P., H. Blüthmann, U.D. Staerz, M. Steinmetz, and H. Von Boehmer. 1988. Tolerance in T-cell-receptor transgenic mice involves deletion of nonmature CD4+8+ thymocytes. Nature. 333:742-746.

40. Posselt, A.M., C.F. Barker, J.E. Tomaszewski, J.F. Markmann, M.A. Choti, and A. Naji. 1990. Induction of donor-specific unresponsiveness by intrathymic islet transplantation. Science. 249:1293-1295.

41. Remuzzi, G., M. Rossini, O. Imberti, and N. Perico. 1991. Kidney graft survival in rats without immunosuppressants after intrathymic glomerular transplantation. Lancet. 337:750-752.

42. Pircher, H., K. Brduscha, U. Steinhoff, M. Kasai, T. Mizuochi, R.M. Zinkernagel, H. Hengartner, B. Kyewski, and K.P. Müller. 1993. Tolerance induction by clonal deletion of $\mathrm{CD} 4+8+$ thymocytes in vitro does not require dedicated antigen-presenting cells. Eur. J. Immunol. 23:669-674.

43. Oehen, S.U., P.S. Ohashi, K. Bürki, H. Hengartner, R.M. Zinkernagel, and P. Aichele. 1994. Escape of thymocytes and mature T cells from clonal deletion due to limiting tolerogen expression levels. Cell. Immunol. 158:342-352.

44. Iwabuchi, K., K. Nakayama, R.L. McCoy, F. Wang, T. Nishimura, S. Habu, K.M. Murphy, and D.Y. Loh. 1992. Cellular and peptide requirements for in vitro clonal deletion of immature thymocytes. Proc. Natl. Acad. Sci. USA 89:9000-9004.

45. Adelstein, S., H. Pritchard-Briscoe, T.A. Anderson, J. Crosbie, G. Gammon, R.H. Loblay, A. Basten, and C.C. Goodnow. 1991. Induction of self tolerance in $\mathrm{T}$ cells but not B cells of transgenic mice expressing little self antigen. Science. 251:1223-1225.

46. Ohtsuru, I., H. Matsuo, T. Fukudome, A. Suenaga, M. Tsujihata, and S. Nagataki. 1995. "Split tolerance" induction by intrathymic injection of acetylcholine receptor in a rat model of autoimmune myasthenia gravis; implications for the design of specific immunotherapies. Clin. Exp. Immunol. 102:462-467.

47. Husby, S., J. Mestecky, Z. Moldoneanu, S. Holland, and C.O. Elson. 1994. Oral tolerance in humans. T cell but not B cell tolerance after antigen feeding. J. Immunol. 152:4663.

48. Singh, R.R., B.H. Hahn, and E.E. Sercarz. 1996. Neonatal peptide exposure can prime $\mathrm{T}$ cells and, upon subsequent immunization, induce their immune deviation: implications for antibody vs. T cell-mediated autoimmunity. $J$. Exp. Med. 183:1613-1621.

49. Gammon, G., E.E. Sercarz, and G. Benichou. 1991. The dominant self and the cryptic self: shaping the autoreactive T-cell repertoire. Immunol. Today. 12:193-195

50. Vafiadis, P., S.T. Bennett, J.A. Todd, J. Nadeau, R. Grabs, C.G. Goodyer, S. Wickramasinghe, E. Colle, and C. Polychronakos. 1997. Insulin expression in human thymus is modulated by INS VNTR alleles at the IDDM2 locus. Nat. Genet. 15:289-292.

51. Pugliese, A., M. Zeller, A. Fernandez, L.J. Zalcberg, R.J. Bartlett, C Ricordi, M. Pietropaolo, G.S. Eisenbarth, S.T. Bennett, and D.D. Patel. 1997. The insulin gene is transcribed in the human thymus and transcription levels correlate with allelic variation at the INS VNTR-IDDM2 susceptibility locus for type 1 diabetes. Nat. Genet. 15:293-297.

52. Egwuagu, C.E., P. Charukamnoetkanok, and I. Gery. 1997. Thymic expression of autoantigens correlates with resistance to autoimmune disease. $J$. Immunol. 159:3109-3112.

53. Jermy, A., D. Beeson, and A. Vincent. 1993. Pathogenic autoimmunity to affinity-purified mouse acetylcholine receptor induced without adjuvant in BALB/c mice. Eur. J. Immunol. 23:973-976.

54. Link, H., O. Olsson, J. Sun, W.Z. Wang, G. Andersson, H.P. Ekre, T. Brenner, O. Abramsky, and T. Olsson. 1991. Acetylcholine receptor-reactive T and B cells in myasthenia gravis and controls. J. Clin. Invest. 87:2191-2195.

55. Ohshima, F., K. Kondo, and T. Tsubaki. 1978. Binding of iodine 125 a-bungarotoxin to the thymus of mice. Arch. Neurol. 35:31-32.

56. Ohashi, P.S., S. Oehen, K. Buerki, H. Pircher, C.T. Ohashi, B. Odermatt, B. Malissen, R.M. Zinkernagel, and H. Hengartner. 1991. Ablation of tolerance and induction of diabetes by virus infection in viral antigen transgenic mice. Cell. 65:304-317.

57. Oukka, M., E. Colucci-Guyon, P. Lan Tran, M. Cohen-Tannoudji, C. Babinet, V. Lotteau, and K. Kosmatopoulos. 1996. CD4 T cell tolerance to nuclear proteins induced by medullary thymic epithelial. Immunity. 4:545-553. 